\title{
Oregon farmers' perspectives on motivations and obstacles to transition to certified organic
}

\author{
Deanna Lloyd ${ }^{\text {a } * \text { and Garry Stephenson }}{ }^{b}$ \\ Oregon State University
}

Submitted August 22, 2019 / Revised January 15 and August 20, 2020 / Accepted August 23, 2020 /

Published online November 10, 2020

Citation: Lloyd, D., \& Stephenson, G. (2020). Oregon farmers' perspectives on motivations and obstacles to transition to certified organic. Journal of Agriculture, Food Systems, and Community

Development, 10(1), 101-115. https://doi.org/10.5304/jafscd.2020.101.017

Copyright (C) 2020 by the Authors. Published by the Lyson Center for Civic Agriculture and Food Systems. Open access under CC-BY license.

\begin{abstract}
This exploratory study investigates perceptions of the transition to certified organic production among farmers in the U.S. state of Oregon who were actively transitioning all or part of their operation to certified organic production. It examines the influence of farmer experience with organic farming systems on motivations and obstacles to transition to certified organic farming. The analysis creates and compares three categories of farmers based on their total years of farming experience and years of farming using organic methods_Experienced Organic Farmers, Beginning Organic Farmers, and Experienced Farmers Beginning Organic — and provides insights into the economic

a * Corresponding author: Deanna Lloyd, Instructor, Department of Crop and Soil Science, Oregon State University; 3017 Agricultural \& Life Sciences Building; Corvallis, OR 97331 USA; deanna.lloyd@oregonstate.edu

b Garry Stephenson, Professor, Department of Crop and Soil Science, and Director, Center for Small Farms \& Community Food Systems, Oregon State University; Crop Science Building 107; Corvallis, OR 97331 USA; +1-541-737-5833; garry.stephenson@oregonstate.edu
\end{abstract}

and ideological motivations for transitioning to certified organic, as well as the economic, production, and marketing obstacles inherent to certified organic transition.

\section{Keywords}

Organic Farming, Organic Certification, Organic Transition, Oregon

\section{Introduction}

Market demand in the United States for certifiedorganic products has shown double-digit growth nearly every year since the implementation of the National Organic Program and the "USDA Organic" label in 2002. In 2018, certified organic food sales increased to US $\$ 47.9$ billion while nonfood sales increased to US $\$ 4.6$ billion. Almost 6\% of total U.S. food sales are certified organic (Organic Trade Association, 2019).

Despite the growth in market demand, there is a lag in the growth of domestic organic production with less than $1 \%$ of total U.S. cropland being certified organic in 2015 (Greene, Ferreira, Carlson, Cooke, \& Hitaj, 2017). Research has indicated that 
farmers may be hesitant to transition their land and production systems to organic due to a number of obstacles, either real or perceived (Cranfield, Henson, \& Holliday, 2010; Farmer, Epstein, Watkins, \& Mincey, 2014; Johnston, 2010; Lau, Hanagriff, Constance, York, VanDelist, \& Higgins, 2010; McBride, Greene, Foreman, \& Ali, 2015; Veldstra, Alexander, \& Marshall, 2014).

In order to transition acreage from conventional to certified organic production, the U.S. Department of Agriculture (USDA)'s National Organic Program requires a three-year transition period. During this time, farmers must comply with all organic regulations, abstain from using prohibited inputs, establish and maintain records of actions and inputs, create an organic system plan, and finally complete the certification process (Organic Foods Production Act Provisions, 2000).

Farmers may manage the transition process using a variety of approaches. For instance, DiGiacomo and King (2015) identified four transition strategies farmers can follow. "Full" transition involves transitioning crops, land, and livestock all at the same time. A "gradual" approach involves transitioning one parcel at a time with the eventual goal of certification for all parcels whereas "split" operations have some land managed conventionally and some certified organic. "Immediate" transition is an option for land that has been fallow, under conservation easement, or can be proven to have received no prohibited inputs in the previous three years. This latter strategy does not require the three-year transition period and can result in immediate certification.

Understanding the motivations and attitudes that influence the decision-making of farmers in transition to organic certification will assist advocates, educators, and researchers to better communicate and support the transition process. Comparative studies have focused on how differences in farmer values and perceptions influence the decision to farm organically (Best, 2008; Beus \& Dunlap, 1990; Cranfield et al., 2010; Stofferahn, 2009). These studies highlight a distinction between economic-motivated farmers and valuesmotivated farmers.

Other studies indicate that farmers may be categorized along a spectrum of pragmatism to idealism (Darnhofer, Schneeberger, \& Freyer, 2005; Fairweather, 1999; Padel, 2001; Schoon \& te Grotenhuis, 2000). The various perspectives and motivations of farmers influence whether they approach transition with an input substitution paradigm or through system redesign (Lamine \& Bellon, 2008). This in turn influences what challenges farmers face during transition.

The literature related to farmer challenges to organic transition and production notes four general categories: economic challenges, production challenges, marketing challenges, and social challenges (Cranfield et al., 2010; Duram, 2000; Johnston, 2010; Koesling, Loes, Flaten, Kristensen, \& Hansen, 2012; Lau et al., 2010; Sahm et al., 2012; Stephenson, Gwin, Powell, \& Garrett, 2012; Strochlic \& Sierra, 2007). The perception of these challenges differs between conventional and organic farmers (Johnston, 2010; Lau et al., 2010).

This study focuses on farmers in the U.S. state of Oregon who have recently transitioned a portion or all of their land to organic production and received organic certification. The 2016 USDA Organic Survey indicates there were a total of 194,769 certified organic acres $(78,820$ hectares) and 461 certified organic farms in the state of Oregon. This accounted for $3.9 \%$ of U.S. certified organic acreage and $3.2 \%$ of its certified organic farms (USDA National Agricultural Statistics Service [NASS], 2017). Oregon has steadily ranked fifth in the amount of certified organic acreage after California, Montana, Wisconsin, and New York, but the state has seen a decline in the number of certified organic farms. In 2014 there were 525 certified organic farms in Oregon, but by 2016 the number of certified organic farms decreased to 461 , a $12.2 \%$ reduction in the number of farms and a loss of 9,397 certified organic acres (3,803 ha) (USDA NASS, 2015; 2017).

\section{Objectives}

Although there are many factors affecting the lagging domestic response to the marketplace demand for organic products, this study is focused on the influence of farming experience on motivations and obstacles Oregon farmers face when transitioning to organic agriculture; this knowledge will 
inform research, education, and policy responses. The objectives are to (1) identify what motivates farmers to make the transition to organic agriculture, and (2) determine the economic, production, and marketing obstacles that farmers face when transitioning to organic agriculture.

The Oregon State University (OSU) Center for Small Farms \& Community Food Systems and Oregon Tilth, Incorporated, collaborated on this study. Oregon Tilth, Inc., a nonprofit organization that focuses on education and advocacy in addition to certification, is interested in learning more about what motivations farmers have and obstacles they face with organic transition so it can tailor its education programs and advocacy efforts to meet farmers' needs. Similarly, the OSU Center for Small Farms \& Community Food Systems is interested in, and dedicated to addressing, the research and educational needs of transitioning farmers.

\section{Methods}

Farmer participants were selected utilizing purposive sampling, a type of non-probability sampling (Bernard, 2013). Oregon Tilth, Inc. provided a list of all farms that were actively transitioning or had certified new land to organic between January 1, 2014, and July 31, 2015. The list yielded 44 Oregon farms. Eleven farms were eliminated from the list: five were noncommercial research or demonstration sites, and an additional six farms were participating in a similar national survey. ${ }^{1}$ This resulted in a final sample of 33 farms. Survey research began during November 2015. For this study, the term "organic" refers to only certified organic farms, methods, inputs, etc., and does not include farms that may practice organic methods without organic certification.

The survey was administered by the Oregon State University Center for Small Farms \& Community Food Systems using paper questionnaires. Survey methods followed the protocols of Salant and Dillman (1994) and Dillman, Smyth, and Christian (2014), with guidance from the Oregon
State University Survey Research Center (OSUSRC). During November 2015, Oregon Tilth, Inc., sent the 33 participants an introductory letter and a copy of the questionnaire with a prepaid business reply envelope by U.S. mail. The letter provided background on the purpose of the survey, introduced the OSU Center for Small Farms \& Community Food Systems as a research partner, and requested the recipient's participation. Each participant received a follow-up postcard two weeks later. One month later, all nonrespondents were mailed a reminder letter and copy of the questionnaire with a prepaid business reply envelope. Twenty-four surveys were completed and returned by mail, and six were completed over the telephone. Of the 33 farms in the sample, two declined to participate and the contact information was incorrect for one, resulting in 30 completed questionnaires and an adjusted response rate of $91 \%$.

\section{Survey Content}

The questionnaire was designed to be short in order to improve the response rate; however, there was a trade-off in that this limited the number of variables that could be examined. The questionnaire conveniently fit on one page with questions on front and back. The questionnaire had four sections: The first section collected basic farm and farmer demographic information, the second section addressed motivations related to transitioning to certified organic production, and the third and fourth sections addressed obstacles to organic transition and production. In these sections, respondents were asked to indicate whether a factor was "a major obstacle," "a minor obstacle," "not an obstacle," or "not applicable/not sure." For both the motivations and obstacles sections, factors identified in published literature helped shape the questions (Cranfield et al., 2010; Johnston, 2010; Lau et al., 2010; Stephenson et al., 2012; Strochlic $\&$ Sierra, 2007). Finally, two open-ended questions probed for advice these farmers had for those considering transition and if there were any additional

\footnotetext{
1 During the same period of this study, the OSU Center for Small Farms \& Community Food Systems and Oregon Tilth, Inc., were conducting a national organic transition survey of farmers in the Organic Environmental Quality Incentives Program (EQUIP) through the USDA Natural Resources Conservation Service (NRCS). To avoid confusing participants, the selection criteria were refined to exclude any farms that had participated in the national survey.
} 
comments about their transition to organic. This study was conducted with approval from the Oregon State University Institutional Review Board to ensure the rights and welfare of the participants.

\section{Data Analysis}

Data were compiled and analyzed using IBM SPSS software (version 23). Initial analysis utilized descriptive statistics including frequencies and cross tabulations to obtain a broad understanding of the data. The small sample size is a constraint, and the statistical analysis was limited to calculations most appropriate for small sample sizes as recommended by the Oregon State University Statistics Department. Fisher's exact test was used to compare a binary response for three farmer groups. Generally, this test is used to compare two groups, but it can be used to compare three groups when used to detect significant differences in the proportion of responses, rather than to prove a hypothesis.

The use of purposive sampling also limits the extent to which the findings can be applied to other farmer populations. In particular, limiting the sample population to farms certified by Oregon Tilth, Inc., prevented us from taking into consideration the viewpoints of farmers who utilize other organic certifiers. However, sampled farms represent a wide spectrum and similar motivations and obstacles that may be found with other farms throughout Oregon and the nation.

\section{Results}

Study Population Characteristics

Oregon has a diverse agricultural economy partly because of the differences in bioregions through- out the state. Survey participants were distributed across seven of Oregon's eight bioregions. However, the majority of participants $(60 \%, n=18)$ were from the Willamette Valley in northwestern Oregon, a hub of agricultural productivity that contains the state's major population centers. The other regions were less represented, but this is likely due to fewer but larger organic farms operating in those areas.

The farms surveyed ranged in size from onethird of an acre to 4,000 acres ( 0.13 ha to 1,620 ha). The most common production system was vegetables, followed by tree fruit, nuts, and berries (Table 1). While 21 farms focused on one production system, six farms integrated two, two farms integrated three, and one farm integrated four systems.

Of the 30 farms surveyed, $50 \%$ had their entire operation certified organic, while $40 \%$ of respondents managed a split operation with part certified organic and part conventional. Ten percent of respondents were in the process of transitioning all or part of their farm to certified organic but had yet to receive official certification.

Respondents ranged in age from 26 to 75 and were somewhat evenly distributed, with $21 \%$ aged $26-35,34 \%$ aged $36-55$, and $45 \%$ aged 56 years or older.

\section{Farmer Experience}

The number of years of farming experience ranged from 1 to 44 years. The USDA defines a beginning farmer or rancher as an individual who has not operated a farm or ranch, or who has operated a farm or ranch for not more than 10 consecutive years (Ahearn \& Newton, 2016). Using this definition, 13 respondents $(43.3 \%)$ are beginning farmers.

Table 1. Farm Production Systems

\begin{tabular}{lc}
\hline Production system & Number of farms* \\
\hline Vegetables (includes seed and cut flowers) & 15 \\
Tree fruit/nuts/berries & 12 \\
Grain/legumes/forage & 9 \\
Livestock/dairy & 4 \\
\hline
\end{tabular}

* Total number of farms equals more than 30 due to some farms integrating multiple production systems. 
Three farmer categories were generated based on the farmers' number of years farming and their number of years of experience with organic and conventional production. Using the USDA definition of 10 years or fewer experience as the dividing line between beginning and experienced farmers, and using the same criteria for beginning or experienced organic farmers, the study population fell into three distinct farmer categories when the question "how many years have you been farming?" was cross tabulated with "how many years farming have you been using 'organic' methods?" (Table 2).

By cross tabulating the data, a Beginning Organic Farmer (BOF) was defined as a farmer with 10 or fewer years of farming experience and who has been farming organically for that same period of time. An Experienced Organic Farmer (EOF) was defined as one who has been farming and farming organically for 11 or more years. The farmer of most interest to this study is the Experienced Farmer Beginning Organic (EFBO). An EFBO has 11 or more years of farming experience total but 10 or fewer years of experience with organic farming. In other words, an EFBO is considered a beginning farmer regarding their organic farming experience. This clear division of producer experience allowed for more detailed analysis of demographics, motivations, and obstacles based on these three categories.

Table 2. Farmer Categories and Sample Size

\begin{tabular}{lccc}
\hline & & $\begin{array}{c}\text { Number of years farming using organic methods } \\
\mathbf{0}-\mathbf{1 0}\end{array}$ & 11 or more \\
\hline Number of years & $0-10$ & $\begin{array}{c}\text { Beginning Organic Farmer } \\
\text { (13 farmers })\end{array}$ & N/A \\
\cline { 2 - 4 } farming & 11 or more & $\begin{array}{c}\text { Experienced Farmer } \\
\text { Beginning Organic } \\
(10 \text { farmers })\end{array}$ & $\begin{array}{c}\text { Experienced Organic } \\
\text { Farmers } \\
(7 \text { farmers })\end{array}$ \\
\hline
\end{tabular}

The 13 farms in the BOF category have an average of 4.7 years of farming experience and the same number of years of organic farming experience. The seven farmers in the EOF category have an average of 34.1 years farming experience and 27 years farming using organic methods. The 10 farmers in the EFBO category have an average of 25.8 years farming experience, but only 3.7 years of organic experience (Table 3).

There is a difference in age of the farmers in the three categories. The EOF category includes six farmers (86\%) 56-75 years old, while the EFBO category has six farmers (60\%) 56-75 years old. The BOF group has two farmers (15\%) 56-75 years old, but overall this group is younger than the other two groups. Nine BOF farmers $(69 \%)$ are under the age of 45 years, with five of those farmers (38\%) 26-35 years old. This age difference is expected since the categories are determined based on years of farming experience.

The average size of farm is notably different among farmer categories (Table 3). In general terms, the more experience one has, the larger the farm, although this may be due to the cropping systems of the different farms. The EFBO farms range in size from 30-4,000 acres with the average size being 1,232 acres. The EOF farms range in size from 1-380 acres, with the average size being 63.3 acres and only one farm having more than 100 acres. The BOF farms range in size from 0.3-56 acres and have the smallest average farm size at only 11.4 acres.

Regarding organic certification, the BOF group had a high percentage of farms that had their entire farm certified organic $(77 \%)$, whereas

Table 3. Average Years of Farming, Average Years of Farming Using "Organic" Methods, and Average Farm Size (Acres)

\begin{tabular}{lccr}
\hline Farmer category & $\begin{array}{c}\text { Average years of } \\
\text { farming experience }\end{array}$ & $\begin{array}{c}\text { Average years of farming } \\
\text { using “organic" methods }\end{array}$ & $\begin{array}{c}\text { Average farm size } \\
\text { (acres | hectares) }\end{array}$ \\
\hline Beginning organic farmer (BOF) & 4.7 & 4.7 & $11.4 \mid 4.6$ \\
Experienced farmer beginning organic (EFBO) & 25.8 & 3.7 & $1,232.0 \mid 499$ \\
Experienced organic farmer (EOF) & 34.2 & 27.0 & $63.3 \mid 25.6$ \\
\hline
\end{tabular}


the EFBO group had a high percentage (70\%) of respondents who utilized split operations (Table 4). Havingestablished markets for their conventional products could be a possible reason for the high percentage of split operations among EFBO farmers.

\section{Farmer Motivations to Transition to Organic} Respondents were asked to reflect on when they first decided to pursue organic certification and indicate whether items on a list were factors in making that decision. There was no restriction on the number of items from the list that could be identified as motivations; respondents were asked to identify all that were applicable. For analysis, two broad categories of motivations were identified: motivations related to ideological/philosophical values and those related to economic/market values. Ideological/philosophical motivations were "fits my and/or my family's values," "concerns about the environment," and "concerns about human health." Economic/market motivations included "potential increase in profit," "access to expanding market for organics," and "specific market opportunity or contract from buyer." Participants were also asked to provide other motivating factors for transition. Aggregate and farmer category responses to each motivation are recorded in Table 5.

Examining the two categories of motivations,

Table 4. Farm Status with Organic Certification

\begin{tabular}{lcccc}
\hline Farmer category & Aggregate & $\begin{array}{c}\text { Beginning organic } \\
\text { farmer (BOF) }\end{array}$ & $\begin{array}{c}\text { Experienced farmer } \\
\text { beginning organic } \\
\text { (EFBO) }\end{array}$ & $\begin{array}{c}\text { Experienced organic } \\
\text { farmer (EOF) }\end{array}$ \\
\hline Entire operation certified organic & 15 & 10 & 4 & 1 \\
& $(50 \%)$ & $(77 \%)$ & $(57 \%)$ & $(10 \%)$ \\
$\begin{array}{l}\text { Split operation with part certified } \\
\text { organic, part non-organic }\end{array}$ & 12 & 3 & 2 & 7 \\
Transitioning all or part of their farm & $(40 \%)$ & $(23 \%)$ & $(29 \%)$ & $(70 \%)$ \\
to certified organic & 3 & 0 & 1 & 2 \\
\hline
\end{tabular}

Table 5. Number and Percentage of Farmers Indicating a Factor was a Motivation to Pursue Organic Certification

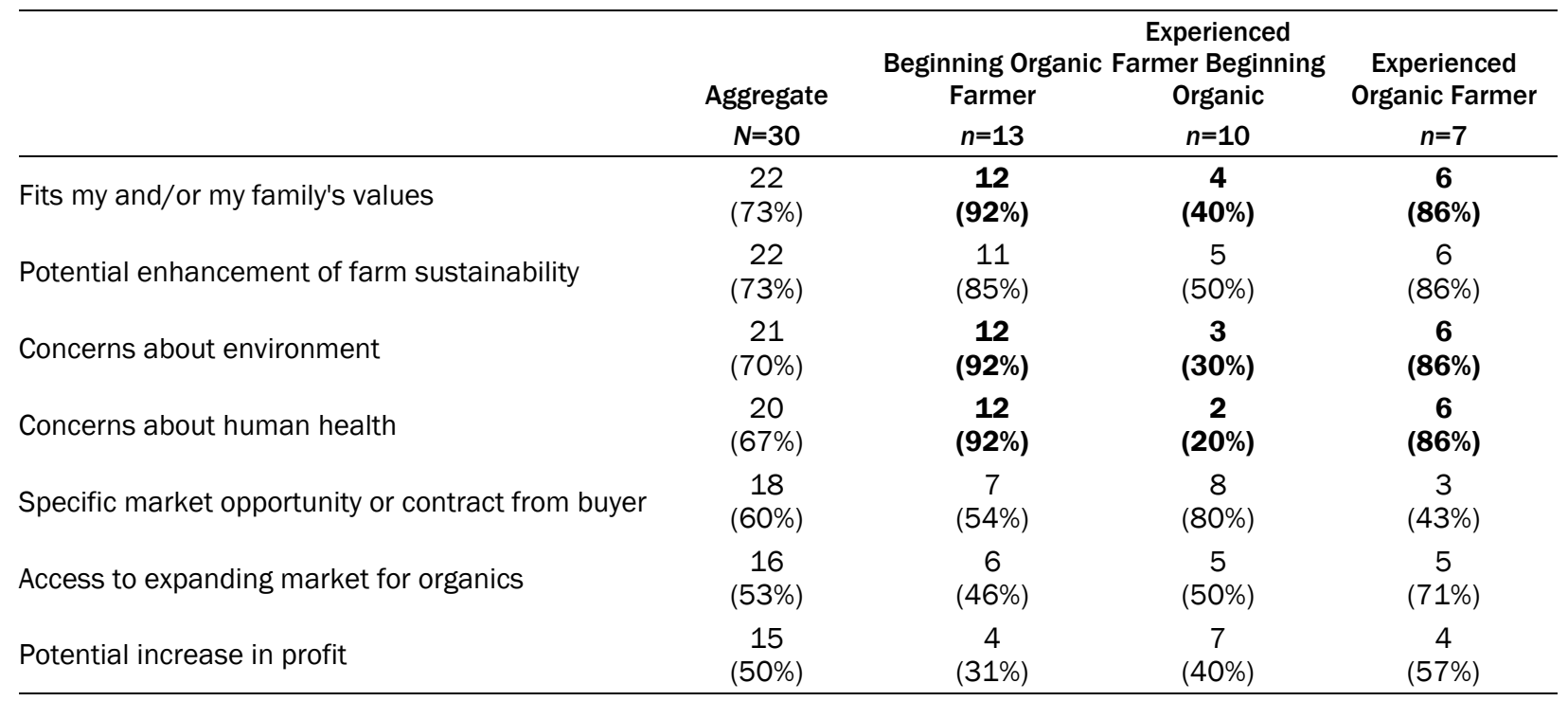

Bold values significantly different at the $p<0.05$ level between the responses of the Beginning Organic Farmer and Experienced Organic Farmer groups versus the Experienced Farmer Beginning Organic group 
economic/market values were noted in the aggregate as less frequent motivations to transition than the ideological/philosophical values. When the respondents are separated by farmer category, however, the EFBO group expressed economic/ market motivations more frequently than ideologi$\mathrm{cal} /$ philosophical values. Eighty percent of the EFBO group indicated "Specific market opportunity or contract from buyer" as a motivation, and this was the most commonly stated motivation for transition for these farmers (Table 5).

For the BOF and EOF groups, ideological/ philosophical motivations were of greater importance in their decision to pursue organic certification than economic/market factors. This contrast in motivations can be seen with a statistically significant difference in the category response to all three of the ideological/philosophical motivations (Table 5). The "fits my and/or my family's value" motivation gains its ranking from the strong importance $\mathrm{EOF}$ and $\mathrm{BOF}$ farmers place on it, despite the EFBO group having a statistically different relation to this factor.

Other motivations to transition to organic offered by the farmers included "getting a new farm" (EOF), "to have a voice" (BOF), and "sustainable nutrient cycling" (EFBO).

\section{Obstacles in Transition to Organic}

Respondents were asked to indicate to what extent specific factors were obstacles to their transition to organic production. Obstacles were grouped into three categories: cost, production, and marketing. Choice of responses to each factor included "a major obstacle," "a minor obstacle," "not an obstacle" or "not applicable/not sure." Due to the small sample size, responses were grouped together for ease of analysis. "A major obstacle" and "a minor obstacle" responses were grouped to indicate that the factor is an obstacle and "not an obstacle" or "not applicable/not sure" responses were taken to indicate a factor not to be an obstacle. The "not an obstacle" and "not applicable/not sure" responses were grouped together because, upon analysis of cropping systems of each respondent, it was determined that the "not applicable/not sure" responses were chosen because they were not applicable to that participant's farming system and thus not obstacles. Table 6 shows the number of respondents who

Table 6. Ranked Obstacles to Organic Transition

\begin{tabular}{|c|c|c|}
\hline & Obstacle category & $\begin{array}{c}\text { Aggregate } \\
N=30\end{array}$ \\
\hline Cost of labor & Economic & $22(73 \%)$ \\
\hline Recordkeeping requirements of organic certification & Production & $22(73 \%)$ \\
\hline Cost of organic certification & Economic & $21(70 \%)$ \\
\hline Weed management & Production & $21(70 \%)$ \\
\hline Pest or disease control & Production & $18(60 \%)$ \\
\hline Cost of organic inputs* & Economic & $16(55 \%)$ \\
\hline Learning process & Production & $16(53 \%)$ \\
\hline Availability of labor & Production & $16(53 \%)$ \\
\hline Managing soil fertility & Production & $14(47 \%)$ \\
\hline Finding buyers/market for my organic products & Marketing & $14(47 \%)$ \\
\hline Access to knowledgeable technical expertise on organic production & Production & $12(40 \%)$ \\
\hline Obtaining adequate prices during transition* & Marketing & $11(38 \%)$ \\
\hline Availability of organic inputs (seed, fertilizer, etc.) & Production & $11(37 \%)$ \\
\hline Availability of organic processing facilities & Marketing & $11(37 \%)$ \\
\hline Planning crop rotations & Production & $7(23 \%)$ \\
\hline Reduced yields & Production & $5(17 \%)$ \\
\hline
\end{tabular}

* $N=29$ due to nonresponse. 
indicated which factors were obstacles to them on their farm.

\section{Obstacles: Aggregate}

Fifty percent or more of the farmers ranked eight factors as obstacles to organic transition (Table 6). The most highly ranked obstacles were "cost of labor" and "recordkeeping requirements of organic certification." Both were identified as an obstacle by $73 \%$ of farmers. Other obstacles noted by over $50 \%$ of farmers included "cost of organic certification" (70\%), "weed management" (70\%), "pest or disease control" (60\%), "cost of organic inputs" (57\%), "availability of labor" (53\%), and "learning process" (53\%).

Economic obstacles on the survey were highly ranked by the aggregate occupying the first, third, and sixth highest ranked obstacles related to costs. The other five obstacles noted by the majority of the aggregate were considered production challenges. No marketing challenges were identified as obstacles to organic transition by $50 \%$ or more of the farmers.

Five of the eight major obstacles noted by the aggregate could be considered external to the farmer. These obstacles ("cost of labor," "recordkeeping requirements of organic certification," "cost of organic certification," "cost of organic inputs" and "availability of labor") are influenced by factors beyond the farmers' control, including domestic policy, market forces, and global affairs.

\section{Obstacles: Beginning Organic Farmers}

The BOF category ranked "cost of labor" (77\%), "recordkeeping requirements of organic certification" $(69 \%)$ and "cost of organic certification" $(62 \%)$ as the highest ranked issues in the same order as the aggregate (Table 7). Also aligning with

Table 7. Number of Farmers within Each Category Ranking a Factor as an Obstacle

\begin{tabular}{|c|c|c|c|c|}
\hline Factor & Aggregate & $\begin{array}{c}\text { Beginning } \\
\text { Organic Farmer }\end{array}$ & $\begin{array}{l}\text { Experienced } \\
\text { Farmer } \\
\text { Beginning } \\
\text { Organic }\end{array}$ & $\begin{array}{l}\text { Experienced } \\
\text { Organic Farmer }\end{array}$ \\
\hline Cost of labor (E) & $22(73 \%)$ & $10(77 \%)$ & $7(70 \%)$ & $5(71 \%)$ \\
\hline Recordkeeping requirements of organic certification $(\mathrm{P})$ & $22(73 \%)$ & $9(69 \%)$ & $8(80 \%)$ & $5(71 \%)$ \\
\hline Cost of organic certification $(E)$ & $21(70 \%)$ & $8(62 \%)$ & $7(70 \%)$ & $6(86 \%)$ \\
\hline Weed management $(\mathrm{P})$ & $21(70 \%)$ & $6(46 \%)$ & $10(100 \%)$ & $5(71 \%)$ \\
\hline Pest or disease control (P) & $18(60 \%)$ & $6(46 \%)$ & $8(80 \%)$ & $4(57 \%)$ \\
\hline Cost of organic inputs* $(E)$ & $16(55 \%)$ & $6(46 \%)$ & $6(67 \%)$ & $4(57 \%)$ \\
\hline Learning process $(\mathrm{P})$ & $16(53 \%)$ & $7(54 \%)$ & $7(70 \%)$ & $2(29 \%)$ \\
\hline Availability of labor $(P)$ & $16(53 \%)$ & $7(54 \%)$ & $5(50 \%)$ & $4(57 \%)$ \\
\hline Managing soil fertility (P) & $14(47 \%)$ & $6(46 \%)$ & $7(70 \%)$ & $1(14 \%)$ \\
\hline Finding buyers/market for my organic products $(\mathrm{M})$ & $14(47 \%)$ & $4(31 \%)$ & $6(60 \%)$ & $2(29 \%)$ \\
\hline Access to knowledgeable technical expertise $(P)$ & $12(40 \%)$ & $7(54 \%)$ & $3(30 \%)$ & $2(29 \%)$ \\
\hline Obtaining adequate prices during transition* $(\mathrm{M})$ & $11(38 \%)$ & $3(25 \%)$ & $6(60 \%)$ & $2(29 \%)$ \\
\hline Availability of organic inputs (seed, fertilizer, etc.) (P) & $11(37 \%)$ & $3(23 \%)$ & $7(70 \%)$ & $1(14 \%)$ \\
\hline Availability of organic processing facilities (M) & $11(37 \%)$ & $3(23 \%)$ & $5(50 \%)$ & $3(43 \%)$ \\
\hline Planning crop rotations $(\mathrm{P})$ & $7(23 \%)$ & $3(23 \%)$ & $3(30 \%)$ & $1(14 \%)$ \\
\hline Reduced yields $(\mathrm{P})$ & $5(17 \%)$ & $0(0 \%)$ & $5(50 \%)$ & $0(0 \%)$ \\
\hline
\end{tabular}


the aggregate was the BOF category perception of "learning process" (54\%) and "availability of labor" $(54 \%)$ as obstacles. A majority of this category ranked "access to knowledgeable technical expertise on organic production" (54\%) as an obstacle, whereas only $40 \%$ of the aggregate identified it as a challenge (Table 7).

Other challenges, including "weed manage- ment," "pest or disease control," "cost of organic inputs," and "managing soil fertility," were noted by $46 \%$ of the BOF as obstacles. Similar to the aggregate, marketing challenges were not identified as obstacles by a majority of the BOF category.

Of the six obstacles identified by over $50 \%$ of the BOF group (Table 8), only one ("learning pro-

Table 8. Obstacles of Concern for Majority of Each Farmer Category

\begin{tabular}{|c|c|c|c|c|}
\hline Rank & Aggregate & $\begin{array}{l}\text { Beginning } \\
\text { Organic Farmer }\end{array}$ & $\begin{array}{l}\text { Experienced Farmer } \\
\text { Beginning Organic }\end{array}$ & $\begin{array}{l}\text { Experienced } \\
\text { Organic Farmer }\end{array}$ \\
\hline 1 & $\begin{array}{c}\text { Cost of labor } \\
(73 \%)\end{array}$ & $\begin{array}{c}\text { Cost of labor } \\
(77 \%)\end{array}$ & $\begin{array}{c}\text { Weed management } \\
(100 \%)\end{array}$ & $\begin{array}{c}\text { Cost of organic certification } \\
(86 \%)\end{array}$ \\
\hline 2 & $\begin{array}{l}\text { Recordkeeping } \\
\text { requirements of } \\
\text { certification } \\
(73 \%)\end{array}$ & $\begin{array}{l}\text { Recordkeeping } \\
\text { requirements of } \\
\text { certification } \\
(69 \%)\end{array}$ & $\begin{array}{l}\text { Recordkeeping } \\
\text { requirements of } \\
\text { certification } \\
(80 \%)\end{array}$ & $\begin{array}{c}\text { Cost of labor } \\
(71 \%)\end{array}$ \\
\hline 3 & $\begin{array}{l}\text { Cost of organic } \\
\text { certification } \\
(70 \%)\end{array}$ & $\begin{array}{l}\text { Cost of organic } \\
\text { certification } \\
(62 \%)\end{array}$ & $\begin{array}{l}\text { Pest of disease control } \\
(\mathbf{8 0} \%)\end{array}$ & $\begin{array}{c}\text { Recordkeeping require- } \\
\text { ments of certification } \\
(71 \%)\end{array}$ \\
\hline 4 & $\begin{array}{c}\text { Weed management } \\
(70 \%)\end{array}$ & $\begin{array}{c}\text { Learning process } \\
(54 \%)\end{array}$ & $\begin{array}{l}\text { Cost of labor } \\
(\mathbf{7 0} \%)\end{array}$ & $\begin{array}{c}\text { Weed management } \\
(71 \%)\end{array}$ \\
\hline 5 & $\begin{array}{l}\text { Pest or disease control } \\
(60 \%)\end{array}$ & $\begin{array}{c}\text { Availability of labor } \\
(54 \%)\end{array}$ & $\begin{array}{l}\text { Cost of organic } \\
\text { certification } \\
(70 \%)\end{array}$ & $\begin{array}{c}\text { Availability of labor } \\
\qquad(57 \%)\end{array}$ \\
\hline 6 & $\begin{array}{l}\text { Cost of organic inputs } \\
\qquad(55 \%)\end{array}$ & $\begin{array}{c}\text { Access to knowledgeable } \\
\text { technical expertise } \\
(54 \%)\end{array}$ & $\begin{array}{l}\text { Cost of organic inputs } \\
\qquad(67 \%)\end{array}$ & $\begin{array}{c}\text { Pest or disease control } \\
(57 \%)\end{array}$ \\
\hline 7 & $\begin{array}{c}\text { Availability of labor } \\
\text { (53\%) }\end{array}$ & - & $\begin{array}{l}\text { Learning process } \\
(50 \%)\end{array}$ & $\begin{array}{c}\text { Cost of organic inputs } \\
(57 \%)\end{array}$ \\
\hline 8 & $\begin{array}{c}\text { Learning process } \\
(53 \%)\end{array}$ & - & $\begin{array}{l}\text { Managing soil fertility } \\
(70 \%)\end{array}$ & - \\
\hline 9 & - & - & $\begin{array}{l}\text { Availability of organic } \\
\text { inputs } \\
(70 \%)\end{array}$ & - \\
\hline 10 & - & - & $\begin{array}{l}\text { Finding buyers/market } \\
(60 \%)\end{array}$ & - \\
\hline 11 & - & - & $\begin{array}{l}\text { Obtaining adequate prices } \\
\text { during transition } \\
(60 \%)\end{array}$ & - \\
\hline 12 & - & - & $\begin{array}{c}\text { Availability of labor } \\
(50 \%)\end{array}$ & - \\
\hline 13 & - & - & $\begin{array}{l}\text { Reduced yields } \\
(50 \%)\end{array}$ & - \\
\hline 14 & - & - & $\begin{array}{c}\text { Availability of organic } \\
\text { processing facilities } \\
(50 \%)\end{array}$ & - \\
\hline
\end{tabular}

Note: Obstacles in bold are common to all farmers. 
cess") could be considered internal to the farmers. The other five obstacles all relate to external factors that could be considered beyond the farmers' sphere of influence.

Obstacles: Experienced Farmers Beginning Organic Over $50 \%$ of the EFBO group identified 14 out of 16 issues as obstacles to organic transition (Table 8 ). The only challenges not noted by the majority were "access to knowledgeable technical expertise on organic production" (30\%) and "planning crop rotations" (30\%).

"Weed management" was identified as a major obstacle to organic transition by $100 \%$ of the EFBO group. There was a statistically significant difference $(p<0.05)$ between the EFBO response and the BOF response, with only $46 \%$ of the BOF group identifying weed management as an obstacle (Table 8).

"Reduced yields" was another obstacle with statistically significant difference between the farmer categories $(p<0.05)$. None of the BOF or EOF farmers noted reduced yields as a barrier, but $50 \%$ of the EFBO group did. Additionally, when the $\mathrm{BOF}$ and $\mathrm{EOF}$ groups were grouped together and compared to the EFBO group, "availability of organic inputs (seed, fertilizer, etc.)" was an obstacle that, although not statistically significant, had substantial differences in response. The EFBO group had $70 \%$ of respondents highlight the availability of organic inputs as an obstacle compared to only $14 \%$ of the EOFs and $23 \%$ of the BOFs. Other obstacles were not statistically significant between groups.

Marketing obstacles ("finding buyers/market for my organic products," "obtaining adequate prices during transition" and "availability of organic processing facilities") were identified by the majority of the EFBO group, in contrast to the other categories and aggregate. Interestingly, 60\% of the EFBO group noted "finding buyers/market for my organic products" as an obstacle, while 80\% had listed "specific market opportunity or contract from buyer" as a motivation for transitioning to organic.

Obstacles: Experienced Organic Farmers

All seven of the obstacles highly ranked by over
$50 \%$ of the EOF group were also highly ranked by the aggregate, although in a different order (Table 8). The only obstacle that the majority of the aggregate identified that the EOF group did not was "learning process."

Only two of the seven obstacles ("weed management" and "pest or disease control") could be considered internal to farmers and their operations. The other five obstacles that were highly ranked by the EOF group could be considered to be external obstacles.

\section{Discussion}

This study focused on Oregon farmers' motivations and perceptions of the obstacles to organic transition. While the literature has identified differences in motivations and obstacles to organic farming between organic and conventional farmers (Johnston, 2010; Lau et al., 2010), by gathering and cross-tabulating demographic data, this study identified distinct farmer categories among organic producers. The clear delineation between the "beginning organic farmer" (BOF), "experienced organic farmer" (EOF), and "experienced farmer beginning organic" (EFBO) was a significant finding and allowed for a more comprehensive interpretation of differing perceptions.

When farmers were asked to consider their motivations for transitioning to organic, differences between farmer categories emerged. The $\mathrm{BOF}$ and EOF groups placed more emphasis on the ideological/philosophical motivators, while the EFBO identified economic/market values as more significant motivators to transition. Surprisingly, a higher percentage of the EOF group was more motivated by access to expanding markets and the potential for increased profit compared to the EFBO group. This may be attributed to the respondents falling along different levels of the farmer spectrum, identified by Darnhofer et al. (2005), which spans from pragmatic to idealistic. "Fits my and/or my family's values" and "potential enhancement of farm sustainability" were the most frequently noted motivations for organic transition by the aggregate. This aligns with the findings of a national survey of farmers transitioning to organic certification that determined "fits my and/or my family's values" was the major motivation for 
organic transition among their aggregate

(Stephenson, Gwin, Schreiner, \& Brown, 2017).

When examining barriers to organic transition identified by the aggregate, eight obstacles were noted by more than $50 \%$ of farmers. Of the eight obstacles, five could be considered influenced by factors outside the direct control of farmers, such as policy, market dynamics, and global affairs. These external obstacles included cost of labor, recordkeeping requirements of organic certification, cost of organic certification, cost of organic inputs, and availability of labor. This aligns with the work of Stephenson et al. (2012), who found that similar external obstacles were of major concern for organic farmers in Oregon.

The cost of labor was the most noted obstacle to organic transition. This aligns with the overall agricultural trend that labor costs are a significant operational expense. When organic and nonorganic production systems were aggregated in the 2017 Census of Agriculture, labor expenses (wages, salaries, and contract labor) represented approximately $12 \%$ of total variable farm expenses and up to $43 \%$ of expenses in greenhouse, vegetable, fruits, and other labor-intensive production systems (USDA ERS, n.d.). Focusing explicitly on organic production, of the US $\$ 4$ billion that organic farmers spent on production costs in 2012, US $\$ 917$ million, or $23 \%$, went to hired labor (USDA NASS, 2015). In fact, cost of labor was the second highest production expense for organic farmers according to the 2012 Census of Agriculture (USDA NASS, 2015). This is a serious consideration for farmers examining the financial sustainability of their business and may influence their decision-making around scaling up. As one EFBO noted, the future availability of farm labor may also become an obstacle and has also been noted in the literature as a concern (Taylor, Charlton, \& Yunez-Naude, 2012).

The economic obstacles of cost of labor, organic certification, and organic inputs were each highly ranked by all farmer categories. The cost of organic certification is required only for certified organic producers and farmers; it was consistent across categories that this was an obstacle and was also found to be a major obstacle for respondents to the national survey of transitioning farmers
(Stephenson et al., 2017). Seventy percent of the aggregate identified this cost as an obstacle to transition. The Organic Certification Cost Share Program is a federal subsidy available for farmers receiving certification, and some participants in their open-ended question responses noted its use. One farmer stated, “... with the government cost share program, it [cost of certification] is not that expensive."

Cost of organic inputs has been noted in the literature as a potential obstacle for organic farmers (Cranfield et al., 2010; Johnston, 2010; Lau et al., 2010), and over half of the aggregate (57\%) noted this as an obstacle. Other cost-related obstacles noted by respondents included the cost of infrastructure and the cost of equipment. As an EFBO wrote, obtaining a "no-till drill, chipping equipment, compost turner and wagon for compost" were significant cost-related obstacles to transition. A BOF echoed this cost challenge, noting the cost of "farm start-up and equipment" as a substantial obstacle.

Among production obstacles, weed management was highly ranked both in our study and in the national survey of transitioning organic farmers (Stephenson et al., 2017). This is definitely a challenge for all producers, but it was interesting to note that only $46 \%$ of the BOF group ranked this as an obstacle, while $100 \%$ of the EFBO and $71 \%$ of the EOF noted it as a challenge. While it is understandable that weed management may be more of a challenge for the EFBO who can no longer use synthetic management approaches, there are other factors that may be contributing to this outcome. One possible explanation is farm size. The BOF group has the smallest acreage of the three categories (averaging 11.4 acres or 4.6 hectares), whereas, the EFBO group has the largest (averaging 1,232 acres or $499 \mathrm{ha}$ ). The more acreage to manage, the more difficult weed control may be, but this is also dependent on the number of different crop types grown on a single farm. An EFBO managing 4,000 acres (1,619 ha) emphasized the importance of weed management and the land that is transitioned stating, "get ground that's not 'dirty' with hard-to-control perennial weeds."

Reduced yield has been identified as a concern for farmers considering the transition to organic 
(Cranfield et al., 2010; Johnston, 2010; Lau et al., 2010). While none of the BOF and EOF respondents identified reduced yields as a challenge, $50 \%$ of EFBO respondents did, a statistically significant difference from the $\mathrm{BOF}$ and $\mathrm{EOF}$ categories. Considering that the EFBO group most recently transitioned, are coming from conventional production, and may still be learning how to incorporate organic techniques, this response can be expected. It would be interesting to follow up with these farmers after they have had more time to practice organic techniques to determine if yields stayed suppressed or if they rose with increased experience and/or changes in soil health, as has been noted in the literature (MacRae, Hill, Mehuys, \& Henning, 1990; Smukler, Jackson, Murphree, Yokota, Koike, \& Smith, 2008).

Within the EFBO group, $70 \%$ identified managing soil fertility as an obstacle, but only $47 \%$ of the aggregate identified it as such. Although many issues were greater obstacles for the aggregate, properly managing soil fertility and health is a key tenet of organic farming; Its importance was further emphasized when farmers were asked to share advice or comments about their transition. In the open-ended response section of the survey, soil health was the most frequently addressed issue after recordkeeping. Comments were remarkably similar and included "work on soil health first," "invest in your soil first," and "there are few shortcuts to soil that is ready to grow!"

While weed management and cost of labor are challenges that could plague both conventional and organic farmers, the recordkeeping requirements of organic certification is a challenge unique to organic production. This task was noted by all categories as an obstacle, and when asked what advice they would share with transitioning farmers, respondents frequently addressed recordkeeping. As one respondent wrote, "The paperwork and inspections are still sort of on the steep part of the learning curve for me, but I do feel the records the certifier require $[\mathrm{s}]$ me to keep are pretty much all important in running a farm business." The sentiment about paperwork being an obstacle, albeit an important and useful one, was echoed by other farmers, who stated, "I would say you should be keeping the records regardless of certification (if that is an obstacle)" and "Becoming certified has been good for my farming practices. It was an additional nudge to keep better records and be very deliberate about everything I do." The difference in perception of recordkeeping as an obstacle may be explained by farmers' preference for actual farming. Recordkeeping may be more of a philosophical obstacle because, as one beginning organic farmer noted, “....my entire profits for 2015 go to pay to prove I don't use chemicals. Why should organic farmers bear the burden of proof?"

The majority of farmers did not perceive market obstacles, but these were important to the EFBO group. "Finding buyers/market for my organic products," "obtaining adequate prices during transition," and "availability of organic processing facilities" were all noted by $50 \%$ or more of the EFBO group as barriers to organic transition.

Following up with EFBO farmers after they have practiced organic techniques for a number of years could provide insight into whether farmers' perceptions change once they have more experience using organic techniques. Further research is needed to determine whether concern for environmental and human health would increase after practicing organic methods, if economic and market values would still dominate decision-making for EFBO farmers, and if they would maintain split operations or move all production to organic.

More research on these categories within larger organic producer groups could allow for a better understanding of the different motivations and obstacles of transitioning organic farmers. To build a more robust understanding of these issues, expanding the sample size and increasing geographic inclusivity would be valuable. The vast majority of organic farmers in Oregon reside within the Willamette Valley, and this is where the majority of survey respondents $(60 \%)$ are located, but Oregon contains seven other distinct agricultural zones. Having adequate representation from each of these zones would bolster understanding of the motivations and obstacles faced by organic producers throughout the state of Oregon.

\section{Conclusion}

This small study is exploratory but significant. It created a new rubric for categorizing organic farm- 
ers based on their years of farming experience and farming system experience that will provide a solid base for future studies. These three distinct categories-experienced organic farmers, beginning organic farmers, and experienced farmers beginning organic — have not been previously identified and explored in this way. In addition, this work explored differences between the three categories. This study will inform more in-depth research and allow for more targeted, and therefore effective, educational and outreach efforts to specific subsets of the organic farmer population and to the spectrum of farmers contemplating transition.

In addition to increasing the number of new beginning organic farmers, more experienced farmers are needed to transition to organic in order to increase the availability of domestic organic products to meet market demand. Outreach and education programs for these farmers should focus more on economic and/or market opportunities as opposed to ideological and/or philosophical motivators (e.g., concerns about human health or the environment).

There are obstacles to organic transition and production that span all farmer categories. Many of the obstacles could be considered external to the farmer and their operation. These external barriers (e.g., recordkeeping requirements of organic certification or cost of organic inputs) are influenced by factors beyond the farmers' control, including policy, market forces, and global affairs. These can be challenging to address, but increasing farmer awareness about these factors and how to moderate their impact through skills such as business planning, recordkeeping, and accounting could be useful for all farmer categories. Additionally, the emphasis on these obstacles suggests a need for more research on and analysis of how farmers are affected by external factors and how they mitigate those impacts.

In order to reach experienced farmers interested in transitioning to organic, education and outreach programs should address obstacles that farmers of all categories regard as challenging, but also on obstacles specific to the farmers categorized in the Experienced Farmer Beginning Organic group. The production obstacles addressed should include weed management, pest or disease control, soil fertility management, and yield reduction. Providing tools and resources to help farmers in this category tackle market obstacles is important and should address how to find buyers or markets for organic products, obtain adequate prices during transition, and access organic processing facilities. Economic obstacles are of concern for every category and include the cost of labor, cost of organic certification, and cost of organic inputs. These economic and market obstacles could be considered external factors. A well-informed farmer will have a better chance of making it through the three-year transition period if they are aware of and have access to resources that address these challenges.

The aggregate, beginning organic farmers, and experienced farmers beginning organic all ranked the learning process as an obstacle. Providing farmers with mentorship and support through their transition could also be a tactic for increasing organic transition and fostering success.

While more in-depth investigation is needed to further understand the motivations and obstacles faced by the diversity of organic and transitioning farmers in the state of Oregon, this study provides information that can be compared to national trends. This work also provides initial insight into these topics and raises more complex questions that can then be fleshed out with more qualitative research approaches. Collaborating with and learning from farmers and their experience will provide the insights necessary to help more farmers successfully transition. As one respondent stated, "the more farmers who transition to organic ... the more we can make it successful for more people."

\section{References}

Ahearn, M. C., \& Newton, D. J. (2009). Beginning farmers and ranchers (Economic Information Bulletin No. 53). U.S. Department of Agriculture, Economic Research Service. https://doi.org/10.2139/ssrn.1408234

Bernard, H. R. (2013). Social research methods: Qualitative and quantitative approaches. Thousand Oaks, CA: SAGE. 
Best, H. (2008). Organic agriculture and the conventionalization hypothesis: A case study from West Germany. Agriculture and Human V alues, 25, 95-106. https://doi.org/10.1007/s10460-007-9073-1

Beus, C. E., \& Dunlap, R. E. (1990). Conventional versus alternative agriculture: The paradigmatic roots of the debate. Rural Sociology, 55(4), 590-616. https://doi.org/10.1111/j.1549-0831.1990.tb00699.x

Cranfield, J., Henson, S., \& Holliday, J. (2010). The motives, benefits, and problems of conversion to organic production. Agriculture and Human V alues, 27, 291-306. https://doi.org/10.1007/s10460-009-9222-9

Darnhofer, I., Schneeberger, W., \& Freyer, B. (2005). Converting or not converting to organic farming in Austria: Farmer types and their rationale. Agriculture and Human Values, 22, 39-52. https://doi.org/10.1007/s10460-004-7229-9

DiGiacomo, G., \& King, R. P. (2015). Making the transition to organic: Ten farm profiles. Sustainable Agriculture Research and Education Program. Retrieved from the University of Minnesota Digital Conservancy: http://hdl.handle.net/11299/181352

Dillman, D. A., Smyth, J. D., \& Christian, L. M. (2014). Internet, phone, mail, and mixed-mode surveys: The tailored design method ( $4^{\text {th }}$ ed.). Hoboken, New Jersey: John Wiley \& Sons Inc.

Duram, L. (2000). Agents' perceptions of structure: How Illinois organic farmers view political, economic, social, and ecological factors. Agriculture and Human Values, 17, 35-48. https://doi.org/10.1023/A:1007632810301

Fairweather, J. R. (1999). Understanding how farmers choose between organic and conventional production: Results from New Zealand and policy implications. Agriculture and Human Values, 16, 51-63. https://doi.org/10.1023/A:1007522819471

Farmer, J. R., Epstein, G., Watkins, S. L., \& Mincey, S. K. (2014). Organic farming in West Virginia: A behavioral approach. Journal of Agriculture, Food Systems, and Community Development, 4(4), 155-171. https://doi.org/10.5304/jafscd.2014.044.007

Greene, C., Ferreira, G., Carlson, A., Cooke, B., \& Hitaj, C. (2017, February). Growing organic demand provides high-value opportunities for many types of producers. Amber $W$ aves. Retrieved from https://www.ers.usda.gov/amber-waves/2017/january-february/growing-organic-demand-provides-highvalue-opportunities-for-many-types-of-producers/

Johnston, S. (2010). Assessing farmer interest in transition to organic production and barriers to expansion of organic production in New York state. Albany, New York: Department of Agriculture and Markets. No longer available online; copy is in possession of the lead author.

Koesling, M., Løes, A. -K., Flaten, O., Kristensen, N. H., \& Hansen, M. W. (2012). Farmers' reasons for deregistering from organic farming. Organic Agriculture, 2, 103-116. https://doi.org/10.1007/s13165-012-0030-y

Lamine, C., \& Bellon, S. (2009). Conversion to organic farming: A multidimensional research object at the crossroads of agricultural and social sciences. A review. Agronomy for Sustainable Development, 29, 97-112. https://doi.org/10.1051/agro:2008007

Lau, M., Hanagriff, R., Constance, D., York, M., VanDelist, B., \& Higgins, L. M. (2010). Discerning differences among producer groups and organic adoption barriers in Texas. Journal of Food Distribution Research, 40(2), $124-164$. Retrieved from https://digitalcommons.calpoly.edu/agb_fac/124/

MacRae, R. J., Hill S. B., Mehuys, G. R., \& Henning, J. (1990). Farm-scale agronomic and economic conversion from conventional to sustainable agriculture. Advances in Agronomy, 43, 155-198. https://doi.org/10.1016/S0065-2113(08)60478-2

McBride, W. D., Greene, C., Foreman, L., \& Ali, M. (2015). The profit potential of certified organic field crop production (ERS Report No. ERR-188). U.S. Department of Agriculture, Economic Research Service. https://doi.org/10.2139/ssrn.2981672

Organic Foods Production Act Provisions, Electronic Code of Federal Regulations $\ 205$ (2000). Retrieved November 18, 2019, from https://ecfr.federalregister.gov/current/title-7/subtitle-B/chapter-I/subchapter-M/part-205

Organic Trade Association. (2019, May 17). U.S. organic sales break through $\$ 50$ billion mark in 2018 [Press release]. Washington D.C.: Organic Trade Association. Retrieved from https://ota.com/news/press-releases/20699

Padel, S. (2001). Conversion to organic farming: A typical example of the diffusion of an innovation? Sociologia Ruralis, 41(1), 40-61. https://doi.org/10.1111/1467-9523.00169 
Sahm, H., Sanders, J., Nieberg, H., Behrens, G., Kuhnert, H., Strohm, R., \& Hamm, U. (2013). Reversion from organic to conventional agriculture: A review. Renewable Agriculture and Food Systems, 28(3), 263-275. https://doi.org/10.1017/S1742170512000117

Salant, P., \& Dillman, D. A. (1994). How to conduct your own survey. New York: John Wiley \& Sons, Inc.

Schoon, B., \& te Grotenhuis, R. (2000). Values of farmers, sustainability and agricultural policy. Journal of Agricultural and Environmental Ethics, 12(1), 17-27. https://doi.org/10.1023/A:1009543907661

Smukler, S. M., Jackson, L. E., Murphree, L., Yokota, R., Koike, S. T., \& Smith, R. F. (2008). Transition to large-scale organic vegetable production in the Salinas Valley, California. Agriculture, Ecosystems \& Environment, 126(3-4), 168188. https://doi.org/10.1016/j.agee.2008.01.028

Stephenson, G., Gwin, L., Powell, M., \& Garrett, A. (2012). Enhancing organic agriculture in Oregon: Research, education and policy. Corvallis: Oregon State University. Retrieved from https://catalog.extension.oregonstate.edu/em9050

Stephenson, G., Gwin, L., Schreiner, C., \& Brown, S. (2017). Breaking new ground: Farmer perspectives on organic transition. Corvallis: Oregon State University. Retrieved from https://ir.library.oregonstate.edu/concern/articles/w95052255

Stofferahn, C. W. (2009). Personal, farm and value orientations in conversion to organic farming. Journal of Sustainable Agriculture, 33(8), 862-884. https://doi.org/10.1080/10440040903303595

Strochlic, R., \& Sierra, L. (2007). Conventional, mixed and "deregistered" organic farmers: Entry barriers and reasons for exiting organic production in California. California Institute for Rural Studies.

Taylor, J. E., Charlton, D., \& Yúnez-Naude, A. (2012). The end of farm labor abundance. Applied Economic Perspectives and Policy, 34(4), 587-598. https://doi.org/10.1093/aepp/pps036

USDA Economic Research Service. (n.d.). Farm labor. Retrieved November 18, 2019, from https://www.ers.usda.gov/topics/farm-economy/farm-labor/

USDA National Agricultural Statistics Service [NASS]. (2015). Organic farming: Results from the 2014 organic survey. Retrieved from https://www.agcensus.usda.gov/Publications/2012/Online Resources/Highlights/Organics/2014 Organic Surve y Highlights.pdf

USDA National Agricultural Statistics Service. (2017). Certified organic survey: 2016 summary. Retrieved from https://www.agcensus.usda.gov/Publications/2012/Online_Resources/Highlights/Organics/2014_Organic_Surve y_Highlights.pdf

Veldstra, M. D., Alexander, C. E., \& Marshall, M. I. (2014). To certify or not to certify? Separating the organic production and certification decisions. Food Policy, 49(2), 429-436. https://doi.org/10.1016/i.foodpol.2014.05.010 